Article

\title{
Provenance Geographical and Climatic Characteristics Influence Budburst Phenology of Southwestern Ponderosa Pine Seedlings
}

\author{
Aalap Dixit ${ }^{1, *}$, Thomas Kolb ${ }^{1}\left(\mathbb{D}\right.$ and Owen Burney ${ }^{2}$ \\ 1 School of Forestry, Northern Arizona University, P.O. Box 15018, Flagstaff, AZ 86011, USA; \\ tom.kolb@nau.edu \\ 2 John T. Harrington Forestry Research Center, New Mexico State University, P.O. Box 359, \\ Mora, NM 87732, USA; oburney@nmsu.edu \\ * Correspondence: ahd42@nau.edu
}

Received: 24 August 2020; Accepted: 1 October 2020; Published: 4 October 2020

check for updates

\begin{abstract}
Ponderosa pine (Pinus ponderosa Lawson \& C. Lawson var. scopulorum Engelm.) forests of the southwestern US are threatened by climate change and deforestation. Information about geographic patterns of provenance variation in budburst phenology is needed to make decisions about selecting seed sources for future planting. In this study, provenance variation in the budburst phenology of ponderosa pine seedlings was examined using common garden studies. Seedlings from 21 provenances, representing an elevational gradient in Arizona and New Mexico, were planted in July 2018 at a ponderosa pine-dominated field site in northern Arizona. Field budburst was monitored weekly on all seedlings in the spring of 2019. Field budburst was compared with budburst timing of the same provenances measured under greenhouse conditions. The hypotheses for this study were that (1) budburst varies among provenances, with earlier budburst in low-elevation provenances, and (2) differences in budburst timing among provenances are consistent for seedlings grown in greenhouse and field environments. Field results show that provenances vary in budburst date and that low- and middle-elevation provenances break bud sooner than high-elevation provenances. Field budburst date had a moderate, positive correlation with provenance mean annual precipitation $(r=0.522)$ and a moderate, negative trend with latitude $(r=-0.413)$. Budburst date of provenances in the greenhouse had a moderate, positive trend with budburst date in the field $(r=0.554)$, suggesting application of greenhouse results to field plantings. Such information about provenance variation and environmental and geographic trends in budburst timing will be useful for developing species-specific seed transfer guidelines and effective assisted migration strategies in a changing climate.
\end{abstract}

Keywords: budburst; phenology; provenance variation; common garden; elevation; latitude; precipitation; Pinus ponderosa

\section{Introduction}

Tree species have considerable genetic variation among provenances and are generally adapted to local climate [1,2]. However, locally adapted provenances are likely to become locally maladapted [3,4] due to the inability to adapt or acclimate to rapid climatic change and associated disturbances. Forests of the southwestern US are already experiencing increases in warming, drought, and tree-killing disturbances [5]. An increase in temperature of over $1{ }^{\circ} \mathrm{C}$ occurred in the southwestern US between 2001-2010, and mean annual temperature is expected to increase between 3 and $5{ }^{\circ} \mathrm{C}$ by the end of this century [6].

Climate warming has already caused an earlier onset of spring in western North America forests [7,8] because tree budburst timing responds to many factors including temperature [9]. 
Earlier budburst due to warmer spring temperatures can have a positive impact on tree performance if early budburst promotes growth by lengthening the growing season, or a negative impact if early budburst results in spring frost damage that kills stems, buds, and leaves $[9,10]$. Spring frost damage has been predicted to increase in frequency with future climate warming due to early budburst [11]. Interactions among multiple factors, such as chilling requirements, temperature, photoperiod, and plant genotype, determine budburst timing [12]. Budburst can vary among tree populations due to local adaptation to the thermal environment [13]. In Pinus, genetic differentiation and clines in growth and phenology have been previously reported [14-16], including among populations of ponderosa pine (Pinus ponderosa Doug. Ex. Laws) from different elevations $[17,18]$.

Ponderosa pine (Pinus ponderosa Lawson \& C. Lawson var. scopulorum Engelm.) forests in the southwestern US are threatened by large-scale mortality due to drought, bark beetle attacks, and wildfires [19], with higher mortality at the low-elevation warm edge of the range [20]. Regeneration and establishment of ponderosa pine seedlings following drought and wildfires has been sparse [21,22]. In order to promote ponderosa pine regeneration in a warming climate, planting low-elevation trailing-edge provenances has been recommended when natural regeneration fails [18,23], as low-elevation provenances have been shown to have traits of drought adaptation [24,25]. However, movement of populations from low elevations to higher elevations could result in earlier budburst and a risk of spring frost damage [26]. Therefore, more information is needed about provenance variation in phenological processes in southwestern ponderosa pines under field conditions to make informed decisions about selecting seed sources for out-planting in a changing climate.

Results of studies performed in controlled greenhouse environments may or may not be scalable to field conditions [27]. Direct comparisons of results from greenhouse and field-based studies are required to determine the predictability of field performance from greenhouse studies. A study of Douglas-fir (Pseudotsuga menziesii (Mirb.) Franco) found a similar pattern of variation in budburst timing among provenances in greenhouse and field environments [28]. This suggests that greenhouse results for budburst timing of provenances are relevant to field performance, but studies are needed for other species such as ponderosa pine.

A field common garden study was used to investigate variation in budburst phenology among 21 southwestern ponderosa pine provenances obtained from different elevations across Arizona and New Mexico. The hypotheses for this study were that (1) budburst varies among provenances, with earlier budburst in low-elevation provenances, and (2) differences in budburst timing among provenances are consistent for seedlings grown in greenhouse and field environments. The objective was to determine if the pattern of earlier budburst by low-elevation provenances found in an earlier greenhouse study was maintained, muted, or amplified under field conditions.

\section{Materials and Methods}

\subsection{Provenance Information}

Ponderosa pine seeds from 21 provenances were used in this study representing a wide elevational range from Arizona and New Mexico (Figure 1). Seeds were obtained for 19 of the 21 provenances from collections at the Northern Arizona University (NAU) Greenhouse Facility located in Flagstaff, Arizona, and New Mexico State University's John T. Harrington Forestry Research Center located in Mora, New Mexico. Seeds were collected for the remaining two provenances in the year 2017. Each provenance consisted of seeds from 3-6 mother trees or a pooled collection without mother tree level information. The selected provenances varied in elevation, mean annual temperature (MAT), and mean annual precipitation (MAP) (Table 1). Climatic information for each provenance was obtained from PRISM (PRISM Climate Group, Oregon State University, http://prism.oregonstate.edu, created 19 September 2020). Provenance origins ranged in MAT from $5.7{ }^{\circ} \mathrm{C}$ to $14.2^{\circ} \mathrm{C}$, in MAP from $364 \mathrm{~mm}$ to $767 \mathrm{~mm}$, and in elevation from $\sim 1600 \mathrm{~m}$ to $\sim 2800 \mathrm{~m}$. Provenance elevation had a moderate, positive correlation with MAP $(r=0.500, p=0.020)$ and a strong, negative correlation with MAT $(r=-0.902$, 
$p<0.0001)$; MAT had a moderate, negative correlation with MAP $(\mathrm{r}=-0.434, p=0.048)$. Latitude had a moderate, negative trend with MAT $(\mathrm{r}=-0.406, p=0.067)$ and longitude had a moderate, positive trend with elevation $(r=0.370, p=0.098)$ (Table 2$)$.

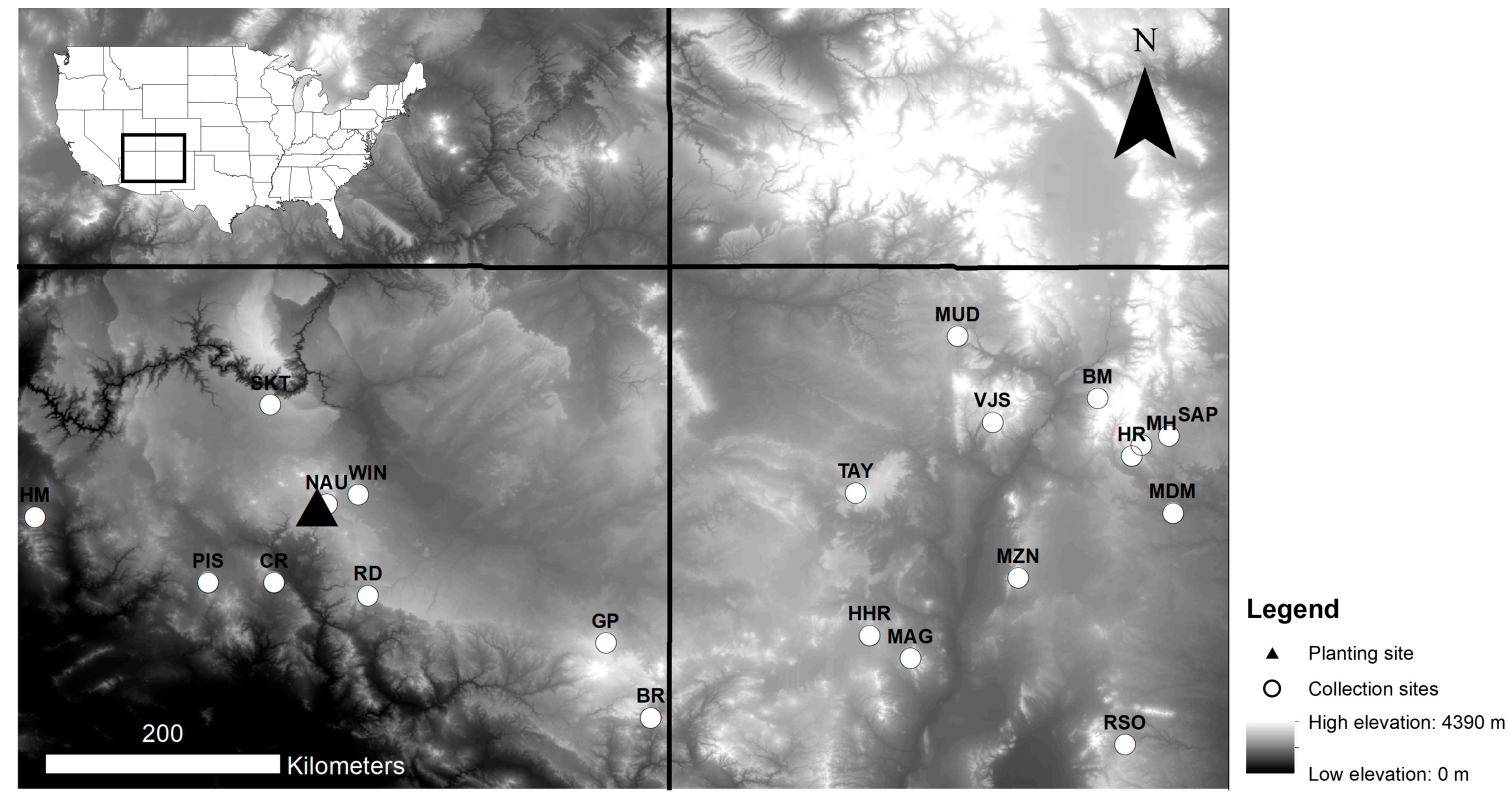

Figure 1. Location map of the 21 provenance collection sites (white circles) of Pinus ponderosa and the location of the field common garden (black triangle).

Table 1. Provenance name, code, latitude, longitude, elevation, mean annual temperature (MAT), and mean annual precipitation (MAP) ordered by increasing elevation. Climate data (30 year normal, 1981-2010) are from PRISM (PRISM Climate Group, Oregon State University, http://prism.oregonstate. edu, created 19 September 2020). Values are means over mother trees at each provenance.

\begin{tabular}{|c|c|c|c|c|}
\hline Provenance (code) & Latitude/Longitude & Elevation (m) & MAT $\left({ }^{\circ} \mathrm{C}\right)$ & MAP (mm) \\
\hline Cherry Road (CR) ${ }^{1}$ & $34.586 /-112.057$ & 1592 & 14.2 & 408 \\
\hline Blue River (BR) & $33.555 /-109.193$ & 1674 & 11.8 & 581 \\
\hline Mesa Del Medio (MDM) & $35.116 /-105.217$ & 1714 & 12.3 & 397 \\
\hline Prescott-Iron Springs Road (PIS) ${ }^{1}$ & $34.585 /-112.559$ & 1846 & 11 & 546 \\
\hline Townsend Winona (WIN) & $35.254 /-111.415$ & 1934 & 10.2 & 398 \\
\hline Hualapai Mountains (HM) ${ }^{1}$ & $35.084 /-113.875$ & 1969 & 11.5 & 403 \\
\hline Ruidoso Service Office (RSO) ${ }^{1}$ & $33.350 /-105.583$ & 1976 & 11.1 & 506 \\
\hline Sapello Rt. 3 (SAP) & $35.700 /-105.250$ & 2050 & 9.8 & 456 \\
\hline South Kaibab Tusayan Dist. (SKT) & $35.939 /-112.084$ & 2067 & 8.9 & 410 \\
\hline Northern Arizona University (NAU) & $35.182 /-111.655$ & 2104 & 8.4 & 540 \\
\hline Rim District (RD) ${ }^{1}$ & $34.487 /-111.343$ & 2244 & 9.4 & 767 \\
\hline HH Ranch (HHR) ${ }^{1}$ & $34.183 /-107.525$ & 2270 & 9.2 & 364 \\
\hline Mineral Hill (MH) ${ }^{1}$ & $35.633 /-105.461$ & 2277 & 8.5 & 528 \\
\hline Mud Springs (MUD) & $36.463 /-106.859$ & 2277 & 6.9 & 443 \\
\hline Manzano Mountains (MZN) & $34.623 /-106.400$ & 2366 & 8.6 & 638 \\
\hline Vallecitos-Jemez Springs (VJS) & $35.809 /-106.589$ & 2436 & 6.8 & 571 \\
\hline Hartman Ridge (HR) & $35.550 /-105.533$ & 2500 & 8.8 & 526 \\
\hline Borrego Mesa (BM) ${ }^{1}$ & $35.990 /-105.794$ & 2560 & 6.3 & 470 \\
\hline Magdalena Mountains (MAG) & $34.006 /-107.215$ & 2565 & 8.9 & 512 \\
\hline Green's Peak (GP) ${ }^{1}$ & $34.126 /-109.535$ & 2760 & 5.7 & 671 \\
\hline Mount Taylor (TAY) ${ }^{1}$ & $35.266 /-107.633$ & 2814 & 6.1 & 722 \\
\hline
\end{tabular}

${ }^{1}$ Provenances used in earlier greenhouse study [25]. 
Table 2. Correlation coefficients between provenance environmental characteristics and budburst date $(n=21)$. Values in parentheses are $p$ values. Boldface type indicates significance $(p<0.05)$.

\begin{tabular}{|c|c|c|c|c|c|}
\hline & Budburst Date & Elevation & MAT & MAP & Latitude \\
\hline \multicolumn{6}{|c|}{ Budburst date } \\
\hline Elevation & $0.528(0.013)$ & & & & \\
\hline MAT & $-0.353(0.116)$ & $-0.902(<0001)$ & & & \\
\hline MAP & $0.522(0.015)$ & $0.500(0.020)$ & $-0.434(0.048)$ & & \\
\hline Latitude & $-0.413(0.062)$ & $0.203(0.375)$ & $-0.406(0.067)$ & $-0.243(0.287)$ & \\
\hline Longitude & $0.058(0.802)$ & $0.370(0.098)$ & $-0.324(0.151)$ & $0.029(0.898)$ & $0.139(0.546)$ \\
\hline
\end{tabular}

\subsection{Field Planting}

Seedlings used for field planting were grown at the John T. Harrington Forestry Research Center of New Mexico State University in Mora, NM. Seedlings began as seeds that were sown in March 2018 into $164 \mathrm{~mL}$ containers and placed in racks with 98 container capacities (Ray Leach Cone-tainers-SC10 Super, RL98 Tray, Stuewe \& Sons, Inc., Tangent, OR, USA). Media was a 2:1:1 mixture of sphagnum peat, perlite, and vermiculite (v:v:v). Seedling emergence rates were uniform across sources with the majority of germination occurring within 14 days after sowing. For the initial three weeks, seeds and germinates were misted 5 times daily, followed by overhead irrigation after total soil moisture dropped to approximately $75 \%$ of container capacity based on gravimetric weights. Supplemental lighting (metal halide lamps; range of 75-125 $1.55 \mu \mathrm{mmol} \mathrm{m}^{-2} \mathrm{~s}^{-1}$ ) was provided when necessary to maintain an $18 \mathrm{~h}$ photoperiod. Daytime and nighttime temperatures were maintained at $21-26^{\circ} \mathrm{C}$ and $18-22^{\circ} \mathrm{C}$, respectively. A starter fertilizer (Peters Professional 25-30 ppm 10-30-20 N-P-K) was applied once per week after planting for a total of 5 weeks, followed by a grower fertilizer (Peters Professional 75-150 ppm 21-5-20 N-P-K) applied once per week, and finally a finisher fertilizer (Plant Marvel Nutriculture 4-25-35 N-P-K) applied once per week.

In July 2018, the greenhouse grown seedlings were planted in a field common garden study at the Arboretum Forest site of the Southwest Experimental Garden Array (SEGA; https://sega.nau.edu; Figure 1) located $10 \mathrm{~km}$ from Flagstaff, Arizona (latitude 35.16, longitude -111.73, and elevation $2200 \mathrm{~m}$ ). The mean annual temperature at the study site was $7.6^{\circ} \mathrm{C}$, and the mean annual precipitation was $555 \mathrm{~mm}$ (1981-2010). During the year of assessment (2019) the mean annual temperature was $6.9^{\circ} \mathrm{C}$, and the annual precipitation was $636 \mathrm{~mm}$. Seedlings were planted in a randomized complete block design at a spacing of $1.2 \mathrm{~m}$ between seedlings. Forty-eight seedlings from 21 provenances each were planted across 4 blocks (1008 total seedlings). Each provenance was planted as a 12-tree linear plot, randomly positioned within each block.

\subsection{Budburst Phenology}

Budburst timing was visually assessed on all live seedlings (658 total; 350 omitted from analysis due to rabbit herbivory; Table 3) in each block of the field planting once per week between May and June, 2019. The protocol used to define budburst was the same as was used in an earlier greenhouse study, where budburst was defined as the Julian date when new needles emerged from the terminal bud [25]. Results from this earlier study [25] were used to compare provenance differences in budburst between our field planting and the greenhouse planting. In the earlier greenhouse study, seedlings were grown from seed at the Northern Arizona University Greenhouse Facility starting in February 2018. Seedlings were watered thrice per week, fertilized twice per week, and exposed to temperatures between 21 and $26^{\circ} \mathrm{C}$, except during the winter dormancy period (mid-November through mid-January), when the seedlings were watered once per week, not fertilized, and exposed to temperatures between 5 and $10{ }^{\circ} \mathrm{C}$. Ten of the 21 provenances used for the field study were included in the greenhouse study (Table 1). For these ten provenances in the greenhouse, budburst was visually accessed on 80 seedlings per provenance (800 total), twice per week, between January and February, 2019. 
Table 3. Mean budburst for each provenance, with standard errors in parentheses (ordered by increasing elevation). Means followed by the same letter do not differ significantly ( $p \leq 0.05$; Tukey's honestly significant difference (HSD) tests; provenance main effect $p=0.0009$ ).

\begin{tabular}{ccc}
\hline Provenance & Number of Seedlings & Budburst Date (Julian Days) \\
\hline CR & 24 & $162.7 \mathrm{ab}(1.05)$ \\
BR & 29 & $165.4 \mathrm{ab}(1.05)$ \\
MDM & 31 & $163.2 \mathrm{ab}(1.37)$ \\
PIS & 36 & $165.2 \mathrm{ab}(0.84)$ \\
WIN & 33 & $163.2 \mathrm{ab}(1.60)$ \\
$\mathrm{HM}$ & 41 & $166.1 \mathrm{ab}(0.74)$ \\
RSO & 28 & $165.1 \mathrm{ab}(0.69)$ \\
$\mathrm{SAP}$ & 30 & $165.5 \mathrm{ab}(0.84)$ \\
$\mathrm{SKT}$ & 39 & $161.4 \mathrm{~b}(1.34)$ \\
$\mathrm{NAU}$ & 30 & $165.9 \mathrm{ab}(0.39)$ \\
RD & 27 & $166.6 \mathrm{a}(0.84)$ \\
$\mathrm{HHR}$ & 39 & $166.1 \mathrm{ab}(1.30)$ \\
MH & 36 & $165.8 \mathrm{ab}(0.83)$ \\
MUD & 30 & $164.2 \mathrm{ab}(1.20)$ \\
MZN & 26 & $165.0 \mathrm{ab}(0.49)$ \\
VJS & 36 & $163.2 \mathrm{ab}(0.52)$ \\
HR & 26 & $163.1 \mathrm{ab}(1.47)$ \\
BM & 30 & $165.1 \mathrm{ab}(0.50)$ \\
MAG & 18 & $169.4 \mathrm{a}(2.13)$ \\
GP & 37 & $168.1 \mathrm{a}(1.06)$ \\
TAY & 32 & $168.9 \mathrm{a}(0.93)$ \\
\hline
\end{tabular}

\subsection{Data Analysis}

Analysis of variance (ANOVA) was used to test for differences in budburst date among the 21 provenances in the field study. We used a mixed-effects model with provenance as a fixed effect and block as a random effect. In order to examine the influence of provenance elevation on budburst phenology, provenances were assigned to elevational groups, which were included in the ANOVA. Elevational groups were defined as follows [25]: low elevation $<2000 \mathrm{~m}$; middle elevation $=2000$ to $2500 \mathrm{~m}$; high elevation $>2500 \mathrm{~m}$. The analysis was conducted on block-level means because individual seedlings were regarded as observational units and row plots of provenances within blocks were regarded as experimental units. Tukey's honestly significant difference (HSD) test was used to detect significant differences between means $(\alpha=0.05)$ among provenances and elevation groups. The relationship between field-measured and greenhouse-measured budburst date was investigated on a subset of field provenances (10 total; Table 1) that was also used in an earlier greenhouse common garden study. The relationships between field and greenhouse budburst dates $(n=10)$ and between field budburst date and environmental characteristics of provenance locations $(n=21)$ were evaluated on provenance means with correlation and regression analyses. Strength of relationship was interpreted as weak when the absolute value of the correlation coefficient (r) was between 0 and 0.3 , moderate between 0.3 and 0.7, and strong between 0.7 and 1.0 [29]. JMP Pro version 14 (SAS Institute Inc., Cary, NC, USA) was used to perform all analyses.

\section{Results}

Budburst date in the field planting differed significantly among provenances ( $p=0.0009$; Table 3$)$, ranging from 161.4 Julian days for South Kaibab Tusayan Dist. (SKT) to 169.4 Julian days for Magdalena Mountains (MAG).

Budburst date in the field planting also differed significantly among elevation groups $(p=0.0026$; Table 4). Low- and middle-elevation provenances had similar budburst dates of about 164 Julian days. 
However, high-elevation provenances broke bud about 3 days later (mean budburst $=\sim 167$ Julian days) than low- and middle-elevation provenances.

Table 4. Mean budburst for each elevation group, with standard errors in parentheses. Means followed by the same letter do not differ significantly ( $p \leq 0.05$; Tukey's honestly significant difference (HSD) tests; provenance main effect $p=0.0026$ ).

\begin{tabular}{cc}
\hline Elevation Group & Budburst Date (Julian Days) \\
\hline Low elevation & $164.6 \mathrm{~b}(0.39)$ \\
Middle elevation & $164.6 \mathrm{~b}(0.22)$ \\
High elevation & $167.7 \mathrm{a}(0.52)$ \\
\hline
\end{tabular}

Correlation analysis revealed some interesting relationships between mean provenance budburst date in the field planting and environmental and geographical characteristics (Table 2). Specifically, budburst date had a moderately positive correlation with elevation $(\mathrm{r}=0.528, p=0.013)$ and MAP $(\mathrm{r}=0.522, p=0.015)$ and a moderately negative trend with latitude $(\mathrm{r}=-0.413, p=0.062)$ (Figure 2$)$.

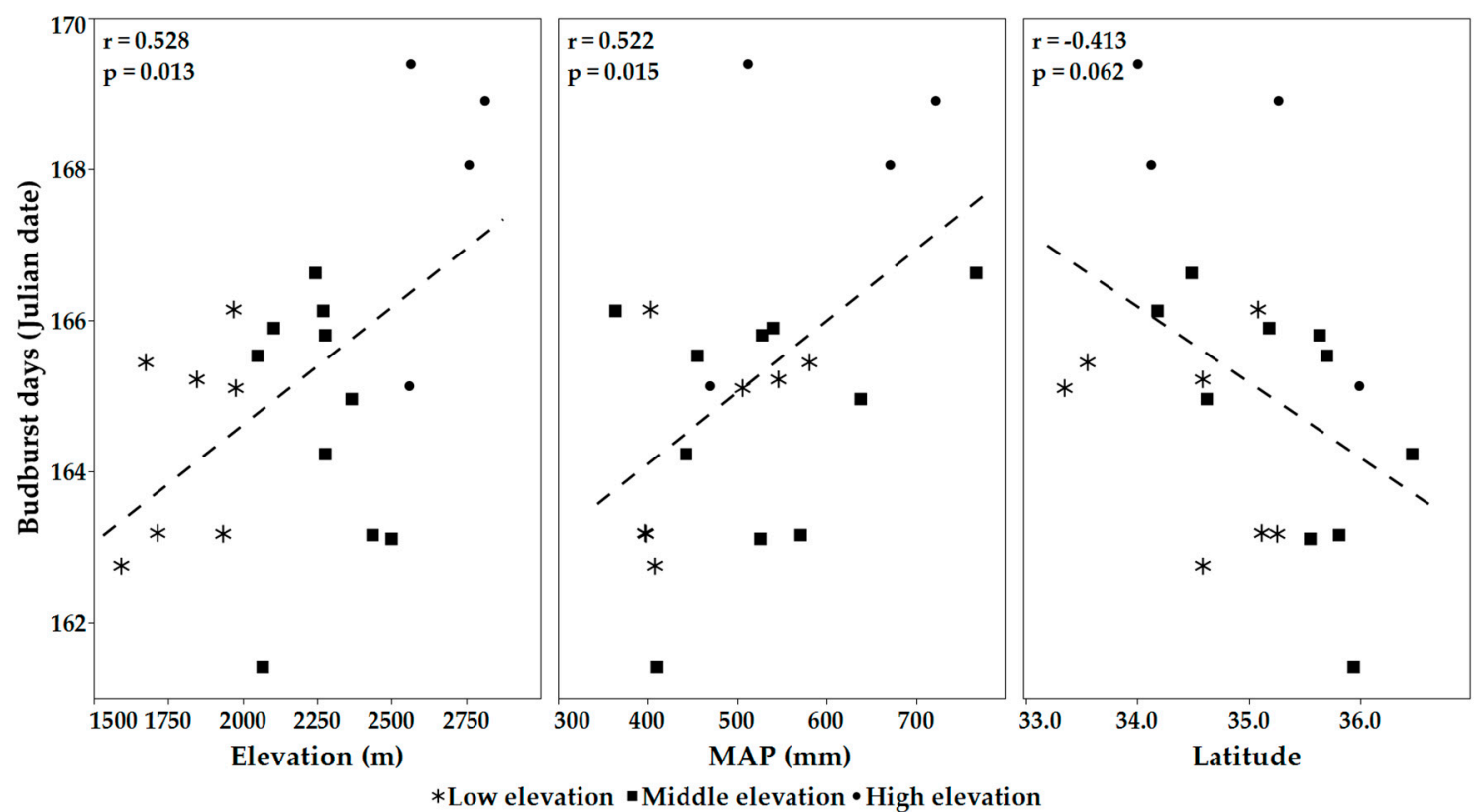

Figure 2. Relationships between provenance mean budburst date and elevation, mean annual precipitation (MAP), and latitude $(n=21)$. Elevation group is shown by different symbols.

A moderate, positive trend ( $r=0.554, p=0.096$; Figure 3) was found between budburst dates measured in the field planting and those measured in the greenhouse planting for the same 10 provenances (Table 1). Budburst occurred much earlier in the greenhouse (Julian days 41 to 45), which was warmed up in mid-January to promote early growth, compared with the field, where budburst occurred in late June (Julian days 163 to 169). In addition, for the same 10 provenances, the budburst range of about 4 days in the greenhouse was less than the range of about 6 days in the field. 


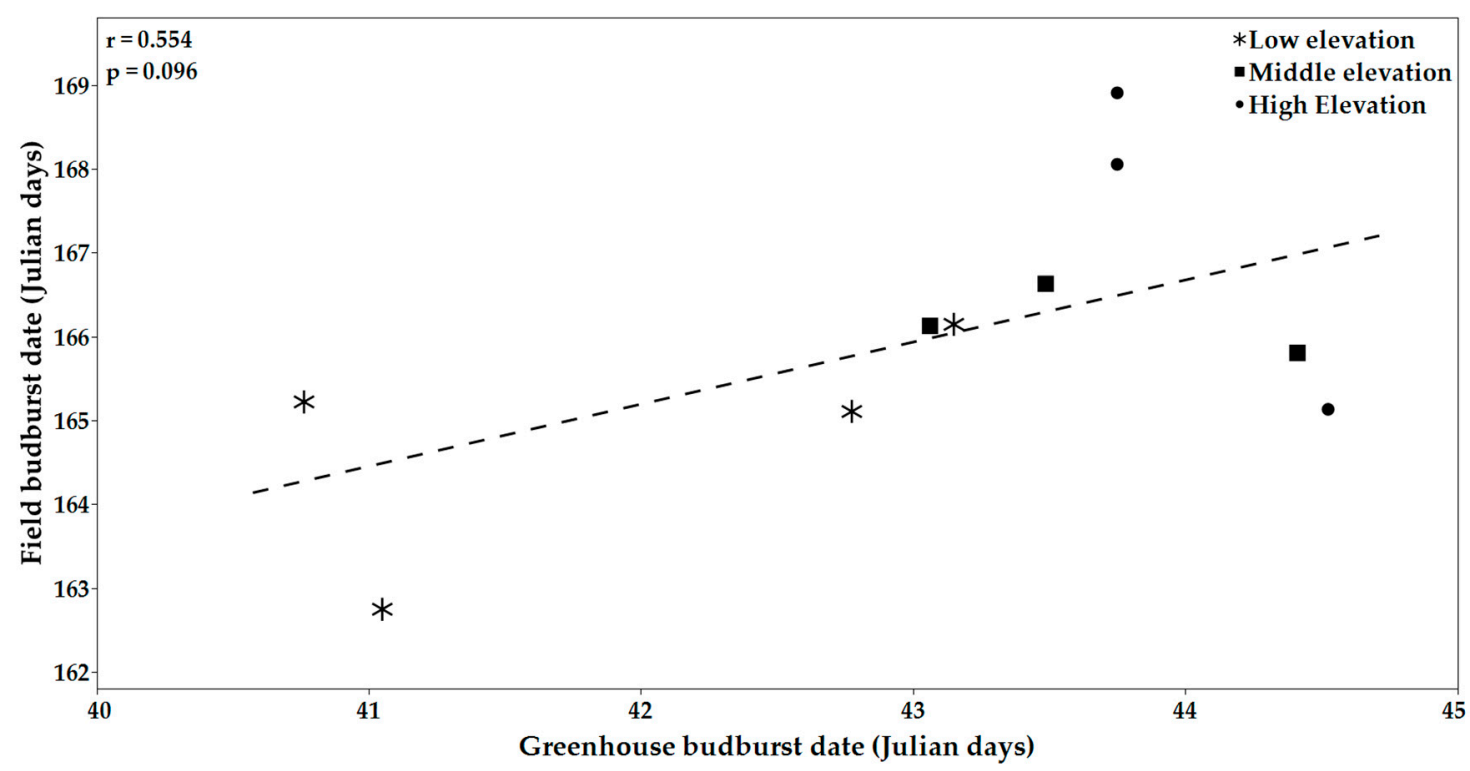

Figure 3. Relationships between mean budburst date measured under greenhouse and field conditions for the same provenances $(n=10)$.

\section{Discussion}

This study investigated variation in budburst phenology among 21 provenances of southwestern ponderosa pine using observations of a field common garden study in the first spring after planting, and of a greenhouse study of 10 of the same provenances. The goal of this study was to test the hypotheses that (1) timing of budburst would vary among provenances in a field planting, and low-elevation provenances would break bud sooner because budburst timing is often genetically controlled and associated with spring frost hardiness [30,31]; and (2) provenance variation in budburst timing measured under field conditions would be related to budburst timing of the same provenances measured under greenhouse conditions. In addition, correlations between field budburst date and provenance environment and geographic characteristics were examined. While the results strongly suggest genetic differences in budburst phenology among southwestern provenances of ponderosa pine, other explanations such as epigenetic and maternal influences were not investigated.

The first hypothesis was supported by significant differences in budburst date among provenances and elevation groups, along with a moderate positive correlation between budburst date and provenance elevation. The maximum difference in field budburst date among provenances was eight days. To understand the ecological significance of this difference, additional field common garden studies at elevations higher than those of the current study are needed to see if this difference is amplified or maintained. Amplification of this difference could predispose seedlings to spring frost damage. On the contrary, if this difference is not amplified, it suggests an opportunity for management in the form of flexibility for seed transfer guidelines pertaining to drought and/or heat resistance. The current study also used observations of seedlings during only the first spring after planting in a year when spring frost damage did not occur. A more complete understanding of the ecological importance of this amount of variation in budburst will require observations over more years [32], especially years with pronounced late-spring frosts.

The pattern of low-elevation provenances breaking bud earlier than high-elevation provenances is likely a result of local adaptation to warm spring temperatures at lower elevations and has been shown to be a highly species-specific response [32]. Similar elevational influence on budburst has been reported in an earlier study showing provenance variation and a negative correlation between elevation and growth potential and duration of shoot elongation in ponderosa pines from Colorado [13]. In addition, the finding in the field study of earlier budburst of low-elevation provenances is consistent with an earlier greenhouse study of some of the same provenances [25]. However, results in this study 
are different from a recent field common garden study in California showing no significant difference in budburst phenology among four provenances of ponderosa pine from different elevations [14], suggesting that findings from one region of ponderosa pine are not always applicable to other regions. Elevation of provenances in that study ranged from $\sim 145 \mathrm{~m}$ to $\sim 1920 \mathrm{~m}$ as compared to $\sim 1600 \mathrm{~m}$ to $2800 \mathrm{~m}$ in this study.

In addition to an elevational trend, a moderate, positive correlation between provenance MAP and budburst timing was found in the current study, showing that provenances from drier areas broke bud sooner than provenances from wetter areas. This result is similar to a study of Douglas fir that reported earlier budburst of provenances from areas with low summer rainfall [33]. However, the result is different from a study involving 35 provenances of cork oak (Quercus suber L.) where no correlation was found between budburst and provenance precipitation and elevation [34]. Such information may have implications for assisted migration of seed sources from drier areas to high-elevation, colder sites that are expected to become drier in the future with climate warming.

An interesting latitudinal trend of earlier budburst by northern provenances was also found in the current study. The results of this latitudinal pattern are different from a study involving beech (Fagus sylvatica L.) provenances in northern Poland showing later flushing by northern provenances [35]. The latitudinal pattern could be the result of earlier fulfillment of the chilling hour requirement by northern provenances, as days to budburst have been shown to decrease as chilling hour accumulation increases in ponderosa pine [36].

The lack of significant correlation between budburst date and MAT $(p=0.116)$ was surprising considering the strong, negative correlation between elevation and MAT $(p<0.0001)$ and a moderate, positive correlation between budburst date and elevation $(p=0.013)$. This result may be due to the lack of direct temperature and precipitation data measured on site for the provenances. The provenance environmental data were obtained using PRISM from an interpolation equation that predicts temperature and precipitation largely from elevation in a particular region [37]. This approach likely does not capture all ecologically relevant microsite climatic variation.

A moderate, positive trend was documented between budburst timing in field and greenhouse environments for the same ten provenances. This relationship is consistent with our second hypothesis and may have applications for investigating provenance variation in phenology in greenhouse experiments. However, the correlation for the relationship had a $p$ value of 0.096 and a sample size of only 10 provenances and therefore must be interpreted with caution. To our knowledge, this is the first report for ponderosa pine provenances of a direct comparison of budburst phenology between field and greenhouse studies. Similar results were reported in a study of Douglas fir provenances, which suggests that greenhouse studies have potential for investigating provenance differences in budburst and predicting patterns in field plantings [24].

\section{Conclusions}

In conclusion, budburst timing varies among provenances of southwestern ponderosa pine. These variations are mainly related to provenance elevation, precipitation, and latitude; low-elevation, drier, and high-latitude provenances break bud sooner than higher elevation, wetter, and lower latitude provenances. In addition, geographic patterns in budburst timing from greenhouse experiments may be applicable to field plantings. More information about budburst timing and risk of spring frost damage is needed for developing species-specific seed transfer guidelines and effective assisted-migration strategies in a changing climate.

Author Contributions: Conceptualization, A.D. and T.K.; Methodology, A.D., T.K., and O.B.; Validation, T.K.; Formal analysis, A.D.; Data collection, A.D.; Writing-original draft preparation, A.D.; Writing-review and editing, A.D., T.K., and O.B.; Supervision, T.K.; Funding acquisition, T.K. and O.B. All authors have read and agreed to the published version of the manuscript.

Funding: This work was supported by the McIntire-Stennis Program project accession numbers $1014222 \& 1002447$ from the USDA National Institute of Food and Agriculture. 
Acknowledgments: The authors thank Philip Patterson and Adair Patterson (Northern Arizona University) for providing seeds, Kelsey Dixit (Coconino Community College) for help with data collection, and Kevin Grady (Northern Arizona University), Tammy Parsons (New Mexico State University), Chris Updike (Northern Arizona University), Zachary Ventrella (Northern Arizona University), and many volunteers for help with establishing the field study.

Conflicts of Interest: The authors declare no conflict of interest.

\section{References}

1. Savolainen, O.; Pyhäjärvi, T.; Knürr, T. Gene Flow and Local Adaptation in Trees. Annu. Rev. Ecol. Evol. Syst. 2007, 38, 595-619. [CrossRef]

2. Hereford, J. A Quantitative Survey of Local Adaptation and Fitness Trade-Offs. Am. Nat. 2009, 173, 579-588. [CrossRef] [PubMed]

3. O'Neill, G.A.; Hamann, A.; Wang, T. Accounting for population variation improves estimates of the impact of climate change on species growth and distribution. J. Appl. Ecol. 2008, 45, 1040-1049. [CrossRef]

4. Grady, K.C.; Ferrier, S.M.; Kolb, T.E.; Hart, S.C.; Allan, G.J.; Whitham, T.G. Genetic variation in productivity of foundation riparian species at the edge of their distribution: Implications for restoration and assisted migration in a warming climate. Glob. Chang. Boil. 2011, 17, 3724-3735. [CrossRef]

5. Garfin, G.; Jardine, A.; Merideth, R.; Black, M.; LeRoy, S. (Eds.) Assessment of Climate Change in the Southwest United States: A Report Prepared for the National Climate Assessment; Island Press/Center for Resource Economics: Washington, DC, USA, 2013. [CrossRef]

6. Melillo, J.M.; Richmond, T.; Yohe, G.W. Climate Change Impacts in the United States: The Third National Climate Assessment; U.S. Global Change Research Program: Washington, DC, USA, 2014. [CrossRef]

7. Schwartz, M.D.; Ahas, R.; Aasa, A. Onset of spring starting earlier across the Northern Hemisphere. Glob. Chang. Boil. 2006, 12, 343-351. [CrossRef]

8. Ault, T.R.; Macalady, A.K.; Pederson, G.T.; Betancourt, J.L.; Schwartz, M.D. Northern Hemisphere Modes of Variability and the Timing of Spring in Western North America. J. Clim. 2011, 24, 4003-4014. [CrossRef]

9. Caffarra, A.; Donnelly, A. The ecological significance of phenology in four different tree species: Effects of light and temperature on bud burst. Int. J. Biometeorol. 2010, 55, 711-721. [CrossRef]

10. Hufkens, K.; Friedl, M.A.; Keenan, T.F.; Sonnentag, O.; Bailey, A.; O’Keefe, J.; Richardson, A.D. Ecological impacts of a widespread frost event following early spring leaf-out. Glob. Chang. Boil. 2012, 18, 2365-2377. [CrossRef]

11. Richardson, A.D.; Hufkens, K.; Milliman, T.; Aubrecht, D.M.; Furze, M.E.; Seyednasrollah, B.; Krassovski, M.B.; Latimer, J.M.; Nettles, W.R.; Heiderman, R.R.; et al. Ecosystem warming extends vegetation activity but heightens vulnerability to cold temperatures. Nature 2018, 560, 368-371. [CrossRef]

12. Howe, G.T.; Aitken, S.N.; Neale, D.B.; Jermstad, K.D.; Wheeler, N.C.; Chen, T.H. From genotype to phenotype: Unraveling the complexities of cold adaptation in forest trees. Can. J. Bot. 2003, 81, 1247-1266. [CrossRef]

13. Rehfeldt, G.E. Genetic Differentiation among Populations of Pinus ponderosa from the Upper Colorado River Basin. Int. J. Plant Sci. 1990, 151, 125-137. [CrossRef]

14. Martínez-Berdeja, A.; Hamilton, J.A.; Bontemps, A.; Schmitt, J.; Wright, J.W. Evidence for population differentiation among Jeffrey and Ponderosa pines in survival, growth and phenology. For. Ecol. Manag. 2019, 434, 40-48. [CrossRef]

15. Wang, T.; Hamann, A.; Yanchuk, A.; O’Neill, G.A.; Aitken, S.N. Use of response functions in selecting lodgepole pine populations for future climates. Glob. Chang. Boil. 2006, 12, 2404-2416. [CrossRef]

16. Chmura, D.J.; Rożkowski, R.; Chałupka, W. Growth and phenology variation in progeny of Scots pine seed orchards and commercial seed stands. Eur. J. For. Res. 2012, 131, 1229-1243. [CrossRef]

17. Rehfeldt, G.E. Genetic Variation in the Ponderosae of the Southwest. Am. J. Bot. 1993, 80, 330. [CrossRef]

18. Rehfeldt, G.E.; Jaquish, B.C.; Sáenz-Romero, C.; Joyce, D.G.; Leites, L.P.; Clair, J.B.S.; López-Upton, J. Comparative genetic responses to climate in the varieties of Pinus ponderosa and Pseudotsuga menziesii: Reforestation. For. Ecol. Manag. 2014, 324, 147-157. [CrossRef]

19. Hicke, J.A.; Meddens, A.J.H.; Kolden, C.A. Recent Tree Mortality in the Western United States from Bark Beetles and Forest Fires. For. Sci. 2016, 62, 141-153. [CrossRef]

20. McDowell, N.G.; Allen, C.D.; Marshall, L. Growth, carbon-isotope discrimination, and drought-associated mortality across a Pinus ponderosa elevational transect. Glob. Chang. Boil. 2010, 16, 399-415. [CrossRef] 
21. Davis, K.T.; Dobrowski, S.Z.; Higuera, P.E.; Holden, Z.A.; Veblen, T.T.; Rother, M.T.; Parks, S.A.; Sala, A.; Maneta, M.P. Wildfires and climate change push low-elevation forests across a critical climate threshold for tree regeneration. Proc. Natl. Acad. Sci. USA 2019, 116, 6193-6198. [CrossRef]

22. Rodman, K.C.; Veblen, T.T.; Battaglia, M.A.; Chambers, M.E.; Fornwalt, P.J.; Holden, Z.A.; Kolb, T.E.; Ouzts, J.R.; Rother, M.T. A changing climate is snuffing out post-fire recovery in montane forests. Glob. Ecol. Biogeogr. 2020. [CrossRef]

23. Kolb, T.; Dixit, A.; Burney, O. Challenges and opportunities for maintaining ponderosa pine forests in the southwestern United States. Tree Plant. Note 2019, 62, 104-112.

24. Kolb, T.E.; Grady, K.C.; McEttrick, M.P.; Herrero, A. Local-Scale Drought Adaptation of Ponderosa Pine Seedlings at Habitat Ecotones. For. Sci. 2016, 62, 641-651. [CrossRef]

25. Dixit, A.; Kolb, T.E. Variation in seedling budburst phenology and structural traits among southwestern ponderosa pine provenances. Can. J. For. Res. 2020. [CrossRef]

26. Grady, K.C.; Kolb, T.E.; Ikeda, D.H.; Whitham, T.G. A bridge too far: Cold and pathogen constraints to assisted migration of riparian forests. Restor. Ecol. 2015, 23, 811-820. [CrossRef]

27. Bacilio, M.; Moreno, M.; Lopez-Aguilar, D.R.; Bashan, Y. Scaling from the growth chamber to the greenhouse to the field: Demonstration of diminishing effects of mitigation of salinity in peppers inoculated with plant growth-promoting bacterium and humic acids. Appl. Soil Ecol. 2017, 119, 327-338. [CrossRef]

28. Malmqvist, C.; Wallin, E.; Lindström, A.; Säll, H. Differences in bud burst timing and bud freezing tolerance among interior and coastal seed sources of Douglas fir. Trees 2017, 31, 1987-1998. [CrossRef]

29. Ratner, B. The correlation coefficient: Its values range between $+1 /-1$, or do they? J. Target. Meas. Anal. Mark. 2009, 17, 139-142. [CrossRef]

30. Ducousso, A.; Guyon, J.; Kremer, A. Latitudinal and altitudinal variation of bud burst in western populations of sessile oak (Quercus petraea (Matt) Liebl). Ann. Sci. For. 1996, 53, 775-782. [CrossRef]

31. Alberto, F.J.; Aitken, S.N.; Alía, R.; Gonzalez-Martinez, S.C.; Hänninen, H.; Kremer, A.; Lefèvre, F.; Lenormand, T.; Yeaman, S.; Whetten, R.; et al. Potential for evolutionary responses to climate change-Evidence from tree populations. Glob. Chang. Boil. 2013, 19, 1645-1661. [CrossRef]

32. Vitasse, Y.; Delzon, S.; Bresson, C.C.; Michalet, R.; Kremer, A. Altitudinal differentiation in growth and phenology among populations of temperate-zone tree species growing in a common garden. Can. J. For. Res. 2009, 39, 1259-1269. [CrossRef]

33. White, T.L.; Ching, K.K.; Walters, J. Effects of provenance, years, and planting location on bud burst of Douglas-fir. For. Sci. 1979, 25, 161-167. [CrossRef]

34. Sampaio, T.; Branco, M.; Guichoux, E.; Petit, R.J.; Pereira, J.S.; Varela, C.; Almeida, M.H. Does the geography of cork oak origin influence budburst and leaf pest damage? For. Ecol. Manag. 2016, 373, 33-43. [CrossRef]

35. Chmura, D.J.; Rozkowski, R. Variability of beech provenances in spring and autumn phenology. Silvae Genet. 2002, 51, 123-127.

36. Wenny, D.L.; Swanson, D.J.; Dumroese, R.K. The Chilling Optimum of Idaho and Arizona Ponderosa Pine Buds. West. J. Appl. For. 2002, 17, 117-121. [CrossRef]

37. Di Luzio, M.; Johnson, G.L.; Daly, C.; Eischeid, J.K.; Arnold, J.G. Constructing Retrospective Gridded Daily Precipitation and Temperature Datasets for the Conterminous United States. J. Appl. Meteorol. Clim. 2008, 47, 475-497. [CrossRef]

(C) 2020 by the authors. Licensee MDPI, Basel, Switzerland. This article is an open access article distributed under the terms and conditions of the Creative Commons Attribution (CC BY) license (http://creativecommons.org/licenses/by/4.0/). 